\title{
The Relevance of Entrepreneurial Education in Lebanese Higher Institutions: A Context Other than Business and Economic Studies
}

\section{Rosie Ghannage}

Department of English Language and Literature Department, Faculty of Letters, USEK, Kaslik, Jounieh, Lebanon

\section{Abstract}

Higher education institutions are being judged nowadays for the ways they respond to the social and economic needs of the society. The relevance of traditional theoretical and organizational models of these institutions are being questioned, and calls for "deep, radical and urgent transformation" are being raised. Entrepreneurship, the

Received: 10 March 2018 Accepted: 10 April 2018

Published: 2 August 2018

Publishing services provided by Knowledge

(c) Rosie Ghannage. This article is distributed under the terms of the Creative Commons

Attribution License, which permits unrestricted use and redistribution provided that the original author and source are credited.

Selection and Peer-review under the responsibility of the International Applied Research Symposium Conference Committee. person's ability to turn ideas into action, being more creative and self-confident, can be one of the essential needs for graduates to confront society's most pressing issues; however, it is not yet sufficiently integrated in Lebanese higher education institutions' curricula, and if any related courses exist, they are only offered in business studies. Thus, the aim of this article is to present the results of a survey on how entrepreneurship is being integrated in some of the Lebanese university curricula, mainly in majors other than business, and also to find out to what extent the recognition of non-formal learning and the development of flexible curricula that enhances university-employer collaboration in innovation and knowledge transfer are being adopted. The article ends with suggestions on how to develop entrepreneurial competences through designing education programs that incorporate a variety of learning outcomes such as having students: (a) develop entrepreneurial drive; (b) build fundamental skills and confidence; and (c) develop entrepreneurial mindsets and entrepreneurial capabilities that lead to entrepreneurial effectiveness.

Keywords: entrepreneurship, learning outcomes, collaboration, entrepreneurial competences 


\section{Introduction}

Higher education institutions are being judged nowadays for the ways they respond to the social and economic needs of the society. A solution to the increase of unemployment and underemployment of graduates is to be sought. For instance, as a result to a study conducted by the American University of Beirut's Alumni Relations Office [1], the researchers acclaim that any "gaps and inconsistencies between the structure of higher education programs and the real needs of the job market need to be resolved." They add that studies should be conducted to "design curricula that suit the job market," and the educational system should "make youths even more attractive to potential ... employers." Moreover, in the Daily Star, Talal Azhari states that the 'dramatic situation' of the underemployed of the youth in Lebanon needs 'innovative solutions' to create crucial jobs [2]. He adds, "the curricula throughout the education system should be adapted to future labor market needs," and the structural gaps between 'needs and competence' should be filled.

Accordingly, many scholars have started to question the relevance of traditional theoretical and organizational models of higher education institutions, and others have already called for a "deep, radical and urgent transformation" [3]. As Potter states, integrating entrepreneurship in our programs is an essential preparation for graduates to tackle society's most pressing issues [4]; however, entrepreneurship is not yet sufficiently considered in Lebanese higher education institutions' curricula, and if any related courses exist, they are only offered in business and economic studies. Given this increasing interest in entrepreneurship education, our intention in this special issue is to highlight the extent to which entrepreneurship is being integrated in some of the Lebanese university curricula, mainly in majors other than business, and to explore the adopted scope of recognition of non-formal learning and the development of flexible curricula that enhances university-employer collaboration in innovation and knowledge transfer. The questions raised are: How can higher education institutions play a role to empower and enhance graduates to find rewarding employment? How can they empower graduates to survive and grow in a dynamic and increasingly global labor market?

The benefits of entrepreneurship education are not limited to start-ups, innovative ventures and new jobs. Entrepreneurship refers to the ability and self-confidence that a person performs to turn ideas into creative actions $[5,6]$. Practically, there are two differing views on what entrepreneurship means. The first is about opportunity identification, business development, self-employment, venture creation and growth, 
that is, becoming on entrepreneur [7, 8]; as Neck and Greene state, the graduates who possess these entrepreneurial attributes are expected to survive and thrive "in a world characterized by increasingly greater levels of uncertainty and unknowability" [9]. Alternatively, the next definition is about personal development, creativity, selfreliance, initiative taking, action orientation, that is, becoming entrepreneurial [10]. Mwasalwiba asserts that the adoption of this definition and approach would affect the educational objectives, the target audiences, the course content designs, the teaching methods and the students' assessment procedures that all lead to a wide diversity of approaches in the higher education domains [10]; hence, becoming entrepreneurial is what the author tries to draw attention to in this article.

According to Gibb, entrepreneurial higher education institutions should be designed to empower staff and students to demonstrate 'enterprise, innovation and creativity' in research and teaching, and they should design educational programs that trigger learners' abilities to pursue and use knowledge across boundaries [11]. To Gibb, Educators are expected to contribute effectively to the enhancement of learning in a societal environment characterized by high levels of uncertainty and complexity; learners and instructors are both dedicated to "creating public value via a process of open engagement, mutual learning, discovery and exchange with all stakeholders in society - local, national and international." Moreover, in the Recommendation on Key Competences for Lifelong Learning (2006), Entrepreneurship is referred to as the individual's ability to turn ideas into action through experiencing: creativity, innovation, risk-taking and ability to plan and manage projects to achieve objectives. In addition, entrepreneurship is meant to support everyone in day-to-day life at home and in society, to make employees more aware of the context of their work, to enable them to seize opportunities, and to provide a foundation for entrepreneurs to establish a social or commercial activity. Hence, it is worth asking ourselves: What do we want our graduates to be? Innovators or followers? Strong, resilient problem solvers or servants of the 'status quo'? As Drucker states, everything has to do with education, or how education is adapted to "the realities and wonderful opportunities of the not-toodistant future" [12]. Badawi adds, "we are living in the 'knowledge era' of human history... education reforms should be oriented to providing students with a knowledge mindset..." (p. 277) [13], and entrepreneurship education is one of the main forms of education that has "a particular role to play in this context."

To check whether entrepreneurship education, non-formal learning and knowledge transfer are being adopted in some higher Lebanese education institutions, a questionnaire was designed and sent to 540 contacts (students and instructors from five 
Lebanese universities). Filled questionnaires from 230 participants were received, and they were distributed as such: 23 MA students, 201 undergraduates from the engineering, education, literature, linguistics, translation, fine arts and sciences, and $6 \mathrm{PhD}$ candidates. In addition, 10 instructors from the departments of literature and linguistics, education, fine arts, and sciences also submitted their answers. To provide consistent data-collection experience for all survey respondents, a broad definition of entrepreneurship and entrepreneurship education was included in questionnaires prepared to find out how universities in Lebanon promote the development of innovative, entrepreneurial projects in their higher education from students and instructors' perspectives. Four six-point scale questions (ranging from strongly agree to totally disagree) were raised to both instructors and students, and one open-ended question was only answered by instructors. The results came as such:

Question 1: The universities in Lebanon promote the development of innovative, entrepreneurial projects in their higher education.

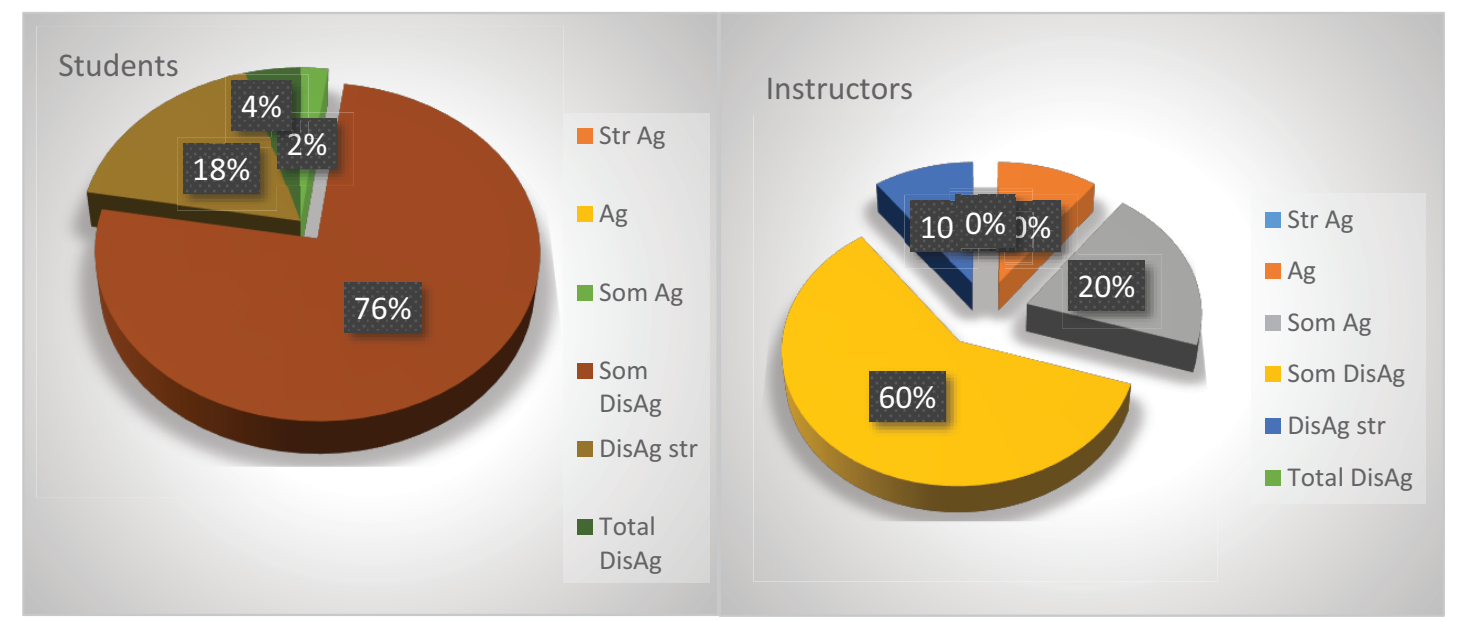

As an answer to question one, the pie graphs show that 76 percent of the students and 60 percent of the instructors somewhat disagree that universities in Lebanon promote the development of innovative, entrepreneurial projects in their higher education. While 18 percent of the students and 20 percent of the instructors (some of them teach in more than one university) strongly disagree. Thus, the compared perception results across instructors and students for question one reveal an approximate agreement that universities in Lebanon do not totally promote the development of innovative, entrepreneurial projects. 
Question 2: The present education system in my university requires substantial change to develop entrepreneurial qualities.
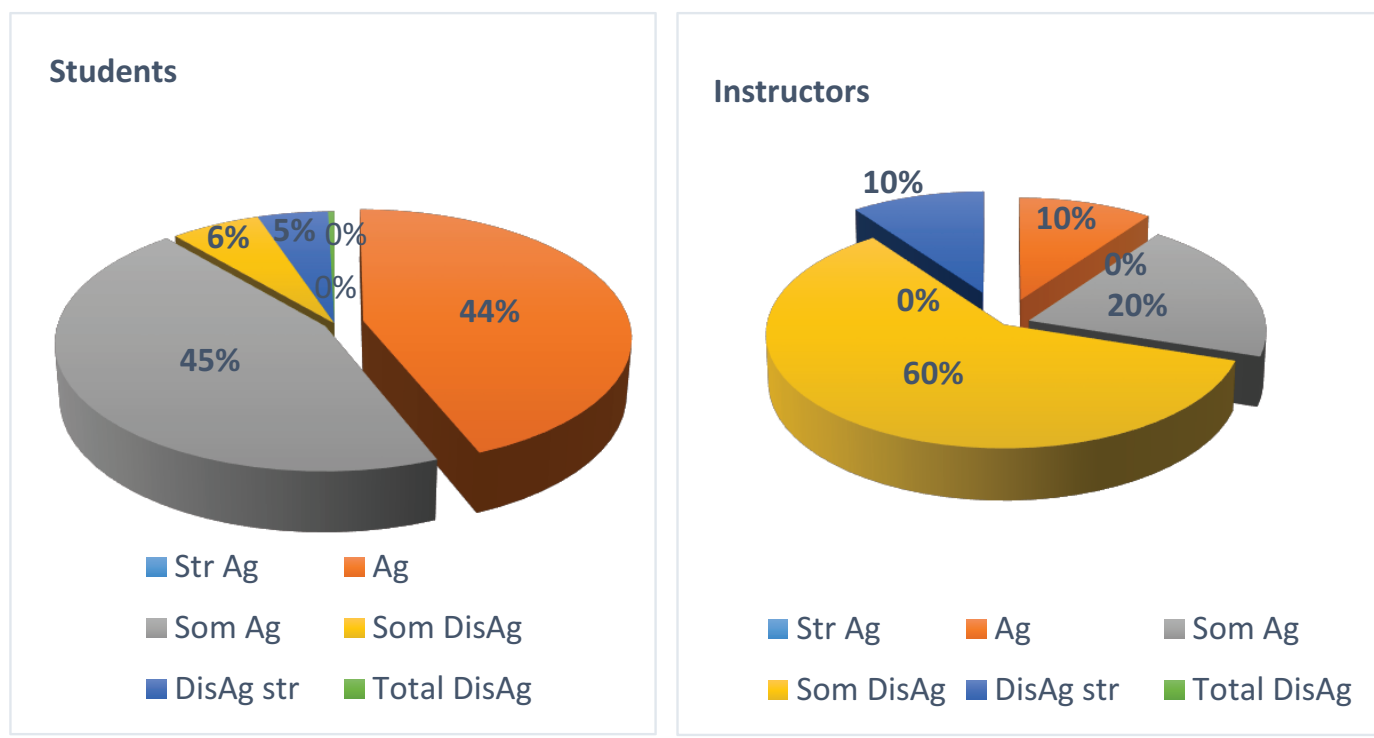

The results of the second question reveal that 44 percent of the students and 10 percent of the instructors agree that the present education system in their universities requires substantial change to develop entrepreneurial qualities. While 45 percent of the students and 20 percent of instructors somewhat agree that the education system needs change. What I find vague in these results is that 40 percent of the instructors have their perspectives range between strongly agree and somewhat agree that the system needs change, while 60 percent of them state that they somewhat disagree that it needs substantial change. However, as previously mentioned, 60 percent of them somewhat disagree that universities in Lebanon promote the development of innovative, entrepreneurial projects-a gap that requests more investigation in future research.

Question 3: The present education system in Lebanese universities is developing these qualities in their students while majoring in your area of specialty. 

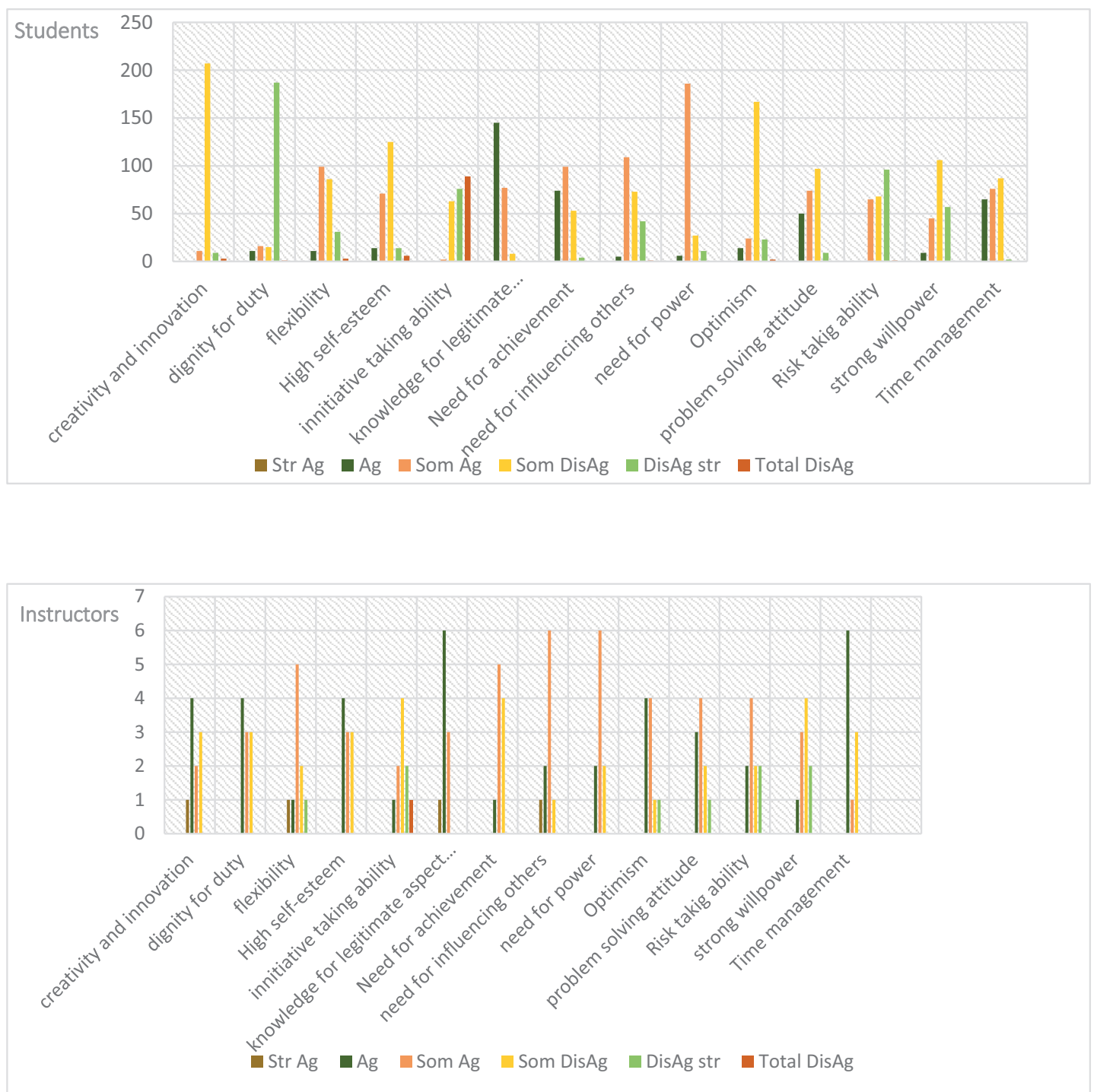

The third question is mainly raised to trace how the entrepreneurship dimensions, such as innovation, risk-taking, creativity and pro-activeness, which is concerned with making things happen by perseverance, adaptability and time management were developed through the present education system in Lebanese universities. The bar graphs that represent the results for students show that the majority of answers related to creativity, innovation, dignity for duty, optimism, risk-taking and the other dimensions ranged between somewhat disagree and totally disagree. However, the instructors' results mostly ranged from somewhat agree to strongly disagree. Although instructors and students see the dimensions from different perspectives, both results reflect that the higher education systems in Lebanese universities need reformation when it comes to the integration of entrepreneurship dimensions in our higher education programs. 
Question 4: Out of the following teaching/learning approaches, which do you suggest your university should reconsider to create entrepreneurial qualities?
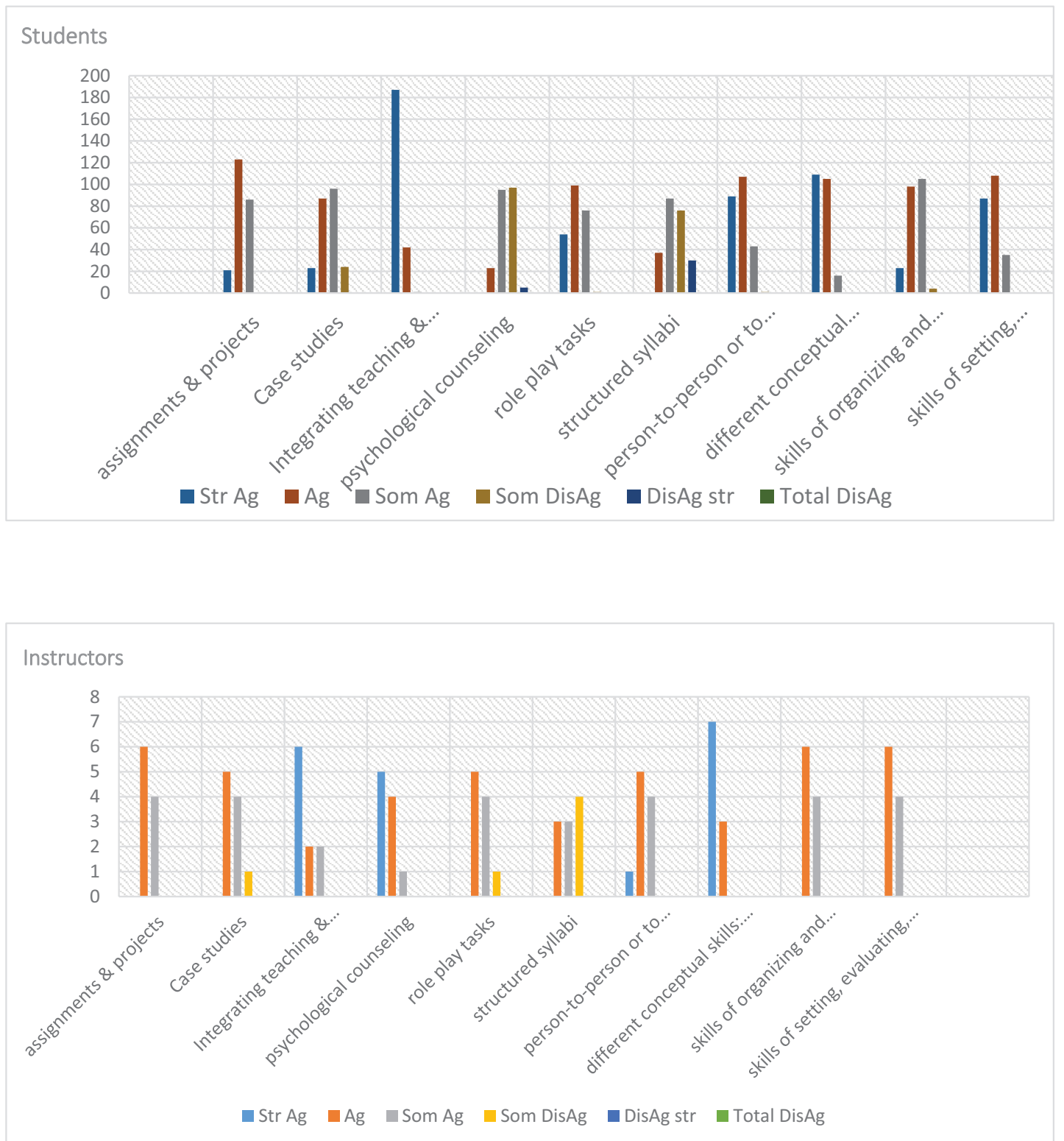

The two aforementioned bar graphs reflect the students and instructors' answers to the fourth question. The results reflect obvious agreement that innovative teaching/learning approaches that develop entrepreneurial education should be adopted since most answers ranged between strongly agree and agree. To develop entrepreneurial skills, the approaches selected were based on Manimala and Thomas [14], and they cover computer and behavioral simulations, case studies discussions, role-playing tasks, collaborative and synergistic learning approaches and actionlearning. 
In addition to the quantitative analysis, one open question was raised, and that was: 'Why do you think we need entrepreneurial higher education institutions?'

A sample of the answers came as such: We believe entrepreneurial education has become a need to:

1. face the complexity of the world and its challenges;

2. catch up with the fundamental changes;

3. move away from strict division of disciplines to lifelike world of learning; and

4. integrate theories and practices to experience the value of what we are learning.

To answer the questions: 'What do we want our graduates to be? Innovators or followers? Strong, resilient problem solvers or servants of the "status quo"?': We agree with what Peter Drucker announces, "everything [has] to do with education... or how education is adapted to the realities and wonderful opportunities of the not-too-distant future" [12].

The author ends this article with the following suggestions:

1. Entrepreneurship has to be an integral part of school AND higher education programs;

2. Curricula should focus upon 'useful' problem-centered sources of knowledge;

3. Faculties should create wider partnerships for learning with cross-disciplinary boundaries;

4. Instructors should apply experiential learning and work as facilitators and moderators; and they should integrate theory and practice in authentic contexts.

Moreover, we need to

1. shift from 'how to run a business' to how to develop a general set of competences applicable in all walks of life;

2. make space in the program for action research to test new methods; and

3. establish support networks.

We should all remember that highly developed language skills are demanded to practice innovation, solve big problem and leverage opportunities; it is "language that brings ideas to life, that inspires, and that creates narrative continuity in organizations". 
Students need to experience the thrill-and certain failure-of leading. Without experiencing leadership and personal growth, "the educational experience is flat, unrealistic and uninspiring" [12]. The author knows that our educational culture tends to be success-focused, and rewards "high achievement," but, as Drucker states, being accountable and taking charge, leadership requires putting oneself on the line, consistently taking risks, and "without exception, sooner or later... failing."

\section{References}

[1] American University of Beirut's Alumni Relations Office. (2009). Retrieved on 14 March 2018 from https://website.aub.edu.lb/communications/media/localnews/ Pages/julog.aspx

[2] Azhari, T. (2014). Youth and unemployment in Lebanon, Daily Star. Retrieved on 14 March 2018 from http://www.dailystar.com.lb/Business/Local/2014/Dec-24/ 282123-youth-and-unemployment-in-lebanon.ashx

[3] Barber, M., Donnelly, K., Rizvi, S., et al. (2013). An avalanche is coming: Higher education and the revolution ahead. London, UK: Institute for Public Policy Research. Retrieved from: https://www.ippr.org/publications/an-avalanche-iscoming-higher-education-and-the-revolution-ahead.

[4] Potter, J. (ed.). (2008). Entrepreneurship and Higher Education. Paris: OECD.

[5] Leitcha, C., Hazlett, S.-A., and Pittaway, L. (2012). Entrepreneurship \& Regional Development, vol. 24, No. 9-10, pp. 733-740. London: Routledge.

[6] NIRAS Consultants, FORA, ECON Pöyry, (2008). Survey of Entrepreneurship Education in Higher Education in Europe. Retrieved from https://www.scribd.com/document/ 43343712/highedsurvey-EU

[7] Fayolle, A. and Gailly, B. (2008). From craft to science: Teaching models and learning processes in entrepreneurship education. Journal of European Industrial Training, vol. 32, no. 7, pp. 569-593. Retrieved from http://dx.doi.org/10.1108/ 03090590810899838

[8] QAA. (2012). Enterprise and entrepreneurship education: Guidance for UK higher education providers. Gloucester, UK: The Quality Assurance Agency for Higher Education. Retrieved on 10 October 2017 from http://www.qaa.ac.uk/en/Publications/ Documents/enterprise-entrepreneurship-guidance.pdf

[9] Neck, H. M., Greene, P. G. (2011). Entrepreneurship education: Known worlds and new frontiers. Journal of Small Business Management, vol. 49, no. 1, p. 5570. Retrieved on 11 October 2017 from http://onlinelibrary.wiley.com/doi/10.1111/ 
j.1540-627X.2010.00314.X/epdf

[10] Mwasalwiba, E. S. (2010). Entrepreneurship education: A review of its objectives, teaching methods, and impact indicators. Education + Training, vol. 52, no. 1, pp. 2047. DOI: http://dx.doi.org/10.1108/00400911011017663 (accessed 17 October 2017).

[11] Gibb, A. A. (2013, submitted). Developing the Entrepreneurial University of the Future. Key Challenges, Opportunities and Responses. Paris: OECD.

[12] Drucker P. (2015). Innovation and entrepreneurship: Principles and practice. London: Routledge.

[13] Badawi, A. A. (2013). TVET and entrepreneurship skills (Chapter 8), in Revisiting Global Trends in TVET: Reflections on Theory and Practice, p. 277. UNESCOUNEVOC International Centre for Technical and Vocational Education and Training. Retrieved on 10 October 2017 from http://www.unevoc.unesco.org/fileadmin/up/ 2013_epub_revisiting_global_trends_in_tvet_book.pdf

[14] Manimala, M. and Thomas, P. (eds.). (2017). Entrepreneurship Education: Experiments with Curriculum, Pedagogy and Target Groups. Singapore: Springer. 